www.mjn.mosuljournals.com

\title{
Effect Of Job Stress On Job Satisfaction Among Nursing Staff In Sulimani Mental Health Hospitals
}

Article information

Article history:

Received January 10, 2019

Accepted April 24, 2019

Available online December 25, 2019

\author{
DOI: 10.33899/mjn.2019.164132 @2020, College of Nursing, University of Mosul. \\ Creative Commons Attribution 4.0 International License \\ https://mjn.mosuljournals.com/article 164132.html \\ Kamal Jummah Ameen \\ Saman Anwar Faraj ${ }^{2}$
}

\begin{abstract}
Background: Job stress is regarded as a harmful factor for both employees and organizations, which negatively affects the effectiveness of employees and efficiency of organizational performance.
\end{abstract}

Many of occupations are exposed to different types of stress in the work place environment. One of these occupations is nursing, which occupies essential role and vital parts of the effectiveness of health care system.

Objective: To investigate the relationship between the effect of job stress on job satisfaction for nurses.

Method: A descriptive study was conducted among nursing staff in mental health hospitals in Sulaimani. The process of the necessary data collection began from 25th May - 10th July 2016 and was obtained through selfreport convenient sample of (75) nurses. They distributed in three hospitals Soz Mental Hospital, Shahid Salahi Muhandis Hospital and Mental Health Center / Teaching Hospital by using questionnaire were divided into three parts: First, socio-demographic characteristics consisted of eight items. Second, Expanded Nursing Stress Scale (ENSS). This consisted of (57) items ranged in nine sub scales. Third, Job Satisfaction Survey (JSS), which included 36 items in nine subscales. Descriptive data and inferential data were used for analysis. validity of the questionnaire was determined through panel of (11) experts in the different fields and work settings.

Results: The analysis of the data figured out that total average job stress among nursing staff at the mental hospitals was "Occasionally stressful- frequently stressful". The subscale death and dying from job stress took the highest level. Nursing staff had job satisfaction, subscale payment (salary) from job satisfaction took the lowest level. There were significant statistical relationships between level of job stress subscales and demographic characteristics except training course dimension. There was no statistical significant correlation between total ENSS and total JSS.

Conclusions: The death of the patients played an important role in perceiving job stress. The lack and delay in salary were a major factor of decreasing job satisfaction, although the level of job stress among nurses does not highly recorded. Also, most of the nurses were satisfied with their work.

Key words : Stress level, Job Satisfaction, Nursing Staff In Mental Health center

\footnotetext{
${ }^{1}$ M.Sc Candidate/ Kirkuk Health Directorate

${ }^{2}$ Lecturer (Supervisor)/ College of Medicine/ University of Sulaimani.
} 


\section{Mosul Journal of Nursing, Vol. 7, No. 2, 2019 ( 109-119 )}

\section{INTRODUCTION}

Stress is now regarded as a biggest problem in many countries around the world (Sabee, 2013). It has been recognized as a major health problem in the $20^{\text {th }}$ century (Maldonado, 2014). It was took the number one of the health problem for both employees and organizations (Watson, 2013).

Job stress is defined as the psychological tension or strain that arises from both employees and organizational stressors in the workplace related to the demands of the job (Finney et al., 2013).

There are constant understandings that job stress described as a complex phenomenon. It is regarded as a harmful factor for employees in terms of health, well-being and job dissatisfaction as well as for organizations in terms of absenteeism and productivity which negatively affects the effectiveness of employees and efficiency of organizational performance (Shikieri and Musa, 2012). It is produced from an interaction between organizational factors and the characteristics of employees in the work place which is related to recent human resource management problems, like higher absenteeism, high rates of turnover, burnout and lower job satisfaction problems (Sullivan, 2013) and (Al Rasasi, et al., 2015).

Many of occupations with totally different jobs are exposed to different types of stress in the work place environments. One of these occupations is nursing (Milutinović et al., 2012). The Nursing profession occupies essential role and vital parts of the effectiveness of health care system (Sullivan, 2013).

Wen-Hsien et al., (2009) identified various sources of job stress in the nursing field. In their environment, nurses are exposed daily to a number of potent stressors, such as conflict with physicians, discrimination, high workload, and persist dealing with death, patients and their families (Mark and Smith, 2011).

They occur when nurses attempt to manage patients and provide services within the scope and field of nursing (Cang-Wong, 2009) .

Numerous studies have shown when there is an imbalance or mismatch between the demands of the work place and a worker's ability to cope (Li et al., 2014) make nursing profession a hard work and job stress would be prevalent and common among nursing staff (Al-Makhaita, et al., 2014).

Job stress in the nursing profession is associated with a variety of negative trends, behavioral, physical and psychological health effects and consequences. Among attitudinal and behavioral consequences mentioned job satisfaction (Long et al., 2014) .

Job dissatisfaction is one of the obvious negative outcomes of job stress among nurses with each work environment (Kawano, 2008).

Job satisfaction is a subjective feeling or attitude regarding various aspects of the job which is influenced by a multitude of factors. It is highly influenced by job stress (Kumar, et al., 2015) .

Recent studies in this area show that the higher levels of nurse job satisfaction are positively linked to improved quality and quantity of care, enhance work environment, increase of productivity, communication performance, selfesteem among staff, organizational citizenship, satisfaction with life and client satisfaction, client interest, mood and indelicacy (Melo, et al., 2011) .

Hence, it is found necessary to assess the level of both job stress and job satisfaction, and figure out the effect of job stress on job satisfaction among the nursing staff especially at the mental health hospitals, because tragic consequences of this relationship are serious, growing concerns for nurses, patients family, and hospitals. 


\section{Mosul Journal of Nursing, Vol. 7, No. 2, 2019 ( 109-119 )}

\section{MATERIALS AND METHOD:}

A descriptive study was conducted among nursing staff in mental health hospitals in Sulaimani. The process of the necessary data collection began from 25th May - 10th July 2016 and was obtained through self-report convenient sample of (75) nurses. They distributed in three hospitals $\mathrm{Soz}$ Mental Hospital, Shahid Salahi Muhandis Hospital and Mental Health Center / Teaching Hospital by using questionnaire were divided into three parts: First, socio-demographic characteristics consisted of eight items.

\section{RESULTS:-}

Table (4-1): Socio-demographic Characteristics of the Sample.

\begin{tabular}{|c|c|c|}
\hline \multicolumn{2}{|c|}{ Number of the total sample $=75$} & $\mathbf{F}(\%)^{\mathrm{a}}$ \\
\hline \multirow{8}{*}{ Age Groups } & $20-24$ & $1 \quad(1.3)$ \\
\hline & $25-29$ & $12(16)$ \\
\hline & $30-34$ & $22(29.3)$ \\
\hline & 35-39 & 14 \\
\hline & $40-44$ & $13(17.3)$ \\
\hline & $45-49$ & $10(13.3)$ \\
\hline & $50-54$ & $2(2.7)$ \\
\hline & $55-59$ & $1 \quad(1.3)$ \\
\hline \multirow[t]{2}{*}{ Gender } & Male & $39(52)$ \\
\hline & Female & $36(48)$ \\
\hline \multirow[t]{2}{*}{ Marital Status } & Unmarried & $13(17.3)$ \\
\hline & Married & $62(82.7)$ \\
\hline \multirow{3}{*}{ Graduation Level } & Nursing Preparatory School & $17(22.7)$ \\
\hline & Institute Diploma of Nursing & $56(74.7)$ \\
\hline & Bachelor of Nursing Science & $2(2.7)$ \\
\hline \multirow{5}{*}{$\begin{array}{c}\text { Years of employment in } \\
\text { mental health }\end{array}$} & 1 to 5 years & $26(34.7)$ \\
\hline & 6 to 10 years & $28(37.3)$ \\
\hline & 11 to 15 years & $9(12)$ \\
\hline & 16 to 20 years & $7(9.3)$ \\
\hline & 21 to 25 years & $5(6.7)$ \\
\hline
\end{tabular}

Second, Expanded Nursing Stress Scale (ENSS). This consisted of (57) items ranged in nine sub scales.

Third, Job Satisfaction Survey (JSS), which included 36 items in nine subscales. Descriptive data and inferential data were used for analysis. validity of the questionnaire was determined through panel of (11) experts in the different fields and work settings. 
Mosul Journal of Nursing, Vol. 7, No. 2, 2019 ( 109-119 )

\begin{tabular}{|c|c|c|}
\hline \multirow{3}{*}{ Economic status } & Sufficient & $\mathbf{8}(10.7)$ \\
\cline { 2 - 3 } & Barely Sufficient & $\mathbf{5 4}(\mathbf{7 2})$ \\
\cline { 2 - 3 } & Insufficient & $\mathbf{1 3}(17.3)$ \\
\hline \multirow{2}{*}{ Training course undertaken } & NO & $\mathbf{2 7}(36)$ \\
\cline { 2 - 3 } & YES & $48(64)$ \\
\hline \multirow{2}{*}{ Profession fits with interest } & NO & $\mathbf{1 8}(24)$ \\
\cline { 2 - 3 } & Yes & $57(76)$ \\
\hline
\end{tabular}

${ }^{\mathrm{a}}$ Frequent (Percent)

Table(4-2): Level of Subscales of Expanded Nursing Stress Scale (ENSS)

\begin{tabular}{|c|c|c|}
\hline Number of the total sampl & & \\
\hline $\begin{array}{c}\text { Socio-demographic } \\
\text { Characteristics }\end{array}$ & Subgroup & $\mathbf{N}(\%)^{\mathrm{a}}$ \\
\hline \multirow{8}{*}{ Age Groups } & 20-24 Years & $1(1.3)$ \\
\hline & 25-29 Years & $12(16)$ \\
\hline & 30-34 Years & $22(29.3)$ \\
\hline & 35-39 Years & 14 (18.7) \\
\hline & 40-44 Years & $13(17.3)$ \\
\hline & 45-49 Years & $10(13.3)$ \\
\hline & 50-54 Years & $2(2.7)$ \\
\hline & 55-59 Years & $1(1.3)$ \\
\hline \multirow{2}{*}{ Gender } & Male & $39(52)$ \\
\hline & Female & $36(48)$ \\
\hline \multirow{2}{*}{ Marital Status } & Unmarried & $13(17.3)$ \\
\hline & Married & $62(82.7)$ \\
\hline \multirow{3}{*}{ Graduation Level } & Nursing Preparatory School & $17(22.7)$ \\
\hline & Institute Diploma of Nursing & $56(74.7)$ \\
\hline & Bachelor of Nursing Science & $2(2.7)$ \\
\hline
\end{tabular}


Mosul Journal of Nursing, Vol. 7, No. 2, 2019 ( 109-119 )

\begin{tabular}{|c|c|c|}
\hline \multirow{4}{*}{ Years of Employment in Mental Health } & 1 to 5 years & $26(34.7)$ \\
\cline { 2 - 3 } & 6 to 10 years & $28(37.3)$ \\
\cline { 2 - 3 } & 11 to 15 years & $9(12)$ \\
\cline { 2 - 3 } & 16 to 20 years & $7(9.3)$ \\
\hline \multirow{2}{*}{ Economic Status } & 21 to 25 years & $5(6.7)$ \\
\cline { 2 - 3 } & Sufficient & $\mathbf{8}(10.7)$ \\
\cline { 2 - 3 } Training Course Undertaken & Barely Sufficient & $54(72)$ \\
\cline { 2 - 3 } & Insufficient & $13(17.3)$ \\
\hline \multirow{2}{*}{ Profession Fits with Interest } & NO & $27(36)$ \\
\cline { 2 - 3 } & YES & $48(64)$ \\
\hline
\end{tabular}

Table(4-3): Level of Subscales of Job Satisfaction Survey (JSS).

\begin{tabular}{|c|c|c|c|c|c|c|c|c|}
\hline \multirow[t]{2}{*}{ No } & \multirow[t]{2}{*}{ (JSS) Subscales } & 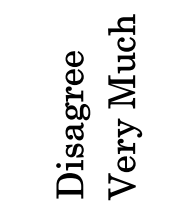 & 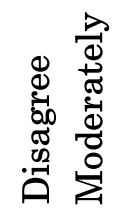 & 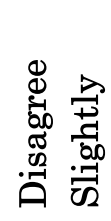 & 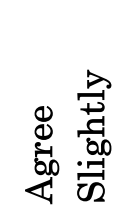 & 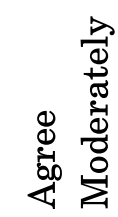 & 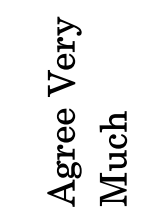 & \multirow{2}{*}{ 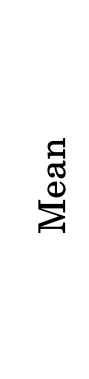 } \\
\hline & & $\begin{array}{c}\mathbf{N} \\
(\%)^{\mathrm{a}}\end{array}$ & $\begin{array}{c}N \\
(\%)^{\mathrm{a}}\end{array}$ & $\begin{array}{c}N \\
(\%)^{\mathrm{a}}\end{array}$ & $\begin{array}{c}N \\
(\%)^{\mathrm{a}}\end{array}$ & $\begin{array}{c}N \\
(\%)^{\mathrm{a}}\end{array}$ & $\begin{array}{c}N \\
(\%)^{a}\end{array}$ & \\
\hline 1 & Pay & $\begin{array}{c}0.25 \\
(0.33)\end{array}$ & $\begin{array}{c}22 \\
(29.2)\end{array}$ & $\begin{array}{c}27 \\
(35.9)\end{array}$ & $\begin{array}{l}20.75 \\
(27.5)\end{array}$ & $\begin{array}{c}5 \\
(6.6)\end{array}$ & $\begin{array}{c}0.25 \\
(0.33)\end{array}$ & 3.11 \\
\hline 2 & Promotion & $\begin{array}{c}1.2 \\
(1.6)\end{array}$ & $\begin{array}{c}10 \\
(13.3)\end{array}$ & $\begin{array}{c}22.2 \\
(29.6)\end{array}$ & $\begin{array}{c}24 \\
(32.1)\end{array}$ & $\begin{array}{c}13.7 \\
(18.3)\end{array}$ & $\begin{array}{c}3.7 \\
(4.9)\end{array}$ & 3.67 \\
\hline 3 & Supervision & $0.25(0.3)$ & $\begin{array}{c}3.7 \\
(5.1)\end{array}$ & $\begin{array}{l}10.2 \\
(14)\end{array}$ & $\begin{array}{c}19.5 \\
(26.8)\end{array}$ & $\begin{array}{c}24.2 \\
(33.2)\end{array}$ & $15(20.6)$ & 4.48 \\
\hline 4 & Fringe benefits & $\begin{array}{c}1.7 \\
(2.2)\end{array}$ & $\begin{array}{r}7.5 \\
(10)\end{array}$ & $\begin{array}{c}19.7 \\
(26.3)\end{array}$ & $\begin{array}{c}26 \\
(34.7)\end{array}$ & $\begin{array}{l}17.2 \\
(23)\end{array}$ & $\begin{array}{c}2.7 \\
(3.6)\end{array}$ & 3.77 \\
\hline 5 & Contingent rewards & $\begin{array}{l}1.5 \\
(2)\end{array}$ & $\begin{array}{l}9.7 \\
(13)\end{array}$ & $\begin{array}{l}20.2 \\
(27)\end{array}$ & $\begin{array}{l}26.2 \\
(35)\end{array}$ & $\begin{array}{c}15.2 \\
(20.3)\end{array}$ & $\begin{array}{c}2 \\
(2.7)\end{array}$ & 3.66 \\
\hline
\end{tabular}


Mosul Journal of Nursing, Vol. 7, No. 2, 2019 ( 109-119 )

\begin{tabular}{|c|c|c|c|c|c|c|c|c|}
\hline 6 & $\begin{array}{l}\text { Operating } \\
\text { conditions }\end{array}$ & $\begin{array}{c}0.5 \\
(0.6)\end{array}$ & $\begin{array}{r}7.5 \\
(10)\end{array}$ & $\begin{array}{c}13.7 \\
(18.3)\end{array}$ & $\begin{array}{l}22.5 \\
(30)\end{array}$ & $\begin{array}{c}21.5 \\
(28.7)\end{array}$ & $\begin{array}{c}9.2 \\
(12.3)\end{array}$ & 4.13 \\
\hline 7 & Coworkers & $\mathbf{0}(\mathbf{0})$ & $\begin{array}{c}1.7 \\
(2.2)\end{array}$ & $\begin{array}{l}6.7 \\
(9)\end{array}$ & $\begin{array}{c}18.5 \\
(24.8)\end{array}$ & $\begin{array}{c}28.7 \\
(38.4)\end{array}$ & $19(25.4)$ & 4.74 \\
\hline 8 & Nature of work & $\mathbf{0}(\mathbf{0})$ & $\begin{array}{l}5.2 \\
(7)\end{array}$ & $\begin{array}{c}13 \\
(17.3)\end{array}$ & $\begin{array}{c}13.2 \\
(17.6)\end{array}$ & $\begin{array}{c}27.5 \\
(36.7)\end{array}$ & $16(21.3)$ & 4.48 \\
\hline 9 & Communication & $\mathbf{0}(\mathbf{0})$ & $\begin{array}{c}1.2 \\
(1.6)\end{array}$ & $\begin{array}{c}8 \\
(10.7)\end{array}$ & $\begin{array}{c}19.2 \\
(25.6)\end{array}$ & $\begin{array}{c}29.5 \\
(39.4)\end{array}$ & $17(22.7)$ & 4.7 \\
\hline \multicolumn{8}{|c|}{ Overall Mean } & 4.08 \\
\hline
\end{tabular}

Table(4-4): Correlations of ENSS with JSS in all Nine sub-scales for Both.

\begin{tabular}{|c|c|c|c|c|c|c|c|c|c|c|}
\hline ENSS & JSS & 1 & 2 & 3 & 4 & 5 & 6 & 7 & 8 & 9 \\
\hline \multirow{2}{*}{1} & $r^{a}$ & 0.04 & 0.06 & -0.1 & 0.12 & -0.01 & 0.1 & 0.05 & $-0.3^{3 * *}$ & -0.08 \\
\hline & $p^{b}$ & 0.7 & 0.5 & 0.1 & 0.3 & 0.9 & 0.2 & 0.6 & 0.01 & 0.4 \\
\hline \multirow{2}{*}{2} & $r^{a}$ & -0.02 & 0.1 & 0.06 & 0.06 & -0.1 & 0.2 & 0.08 & $-0.23^{*}$ & -0.07 \\
\hline & $p^{b}$ & 0.8 & $\mathbf{0 . 3}$ & 0.5 & 0.6 & 0.3 & 0.06 & 0.4 & 0.04 & 0.5 \\
\hline \multirow{2}{*}{3} & $r^{a}$ & -0.09 & -0.05 & 0.08 & -0.06 & -0.01 & 0.003 & -0.08 & -0.14 & -0.03 \\
\hline & $p^{b}$ & 0.3 & 0.6 & 0.4 & 0.5 & 0.9 & 0.9 & 0.4 & 0.2 & 0.7 \\
\hline \multirow{2}{*}{4} & $r^{a}$ & 0.007 & -0.01 & 0.09 & 0.2 & -0.1 & 0.14 & -0.1 & -0.17 & 0.01 \\
\hline & $p^{b}$ & 0.9 & 0.9 & 0.4 & $\mathbf{0 . 0 8}$ & 0.1 & 0.2 & 0.3 & 0.1 & 0.8 \\
\hline \multirow{2}{*}{5} & $r^{a}$ & 0.07 & 0.07 & 0.03 & 0.1 & 0.005 & 0.1 & 0.1 & -0.2 & $\mathbf{0 . 0 6}$ \\
\hline & $p^{b}$ & 0.5 & 0.5 & 0.7 & 0.3 & 0.9 & 0.2 & 0.1 & 0.054 & 0.5 \\
\hline \multirow{2}{*}{6} & $r^{a}$ & 0.07 & 0.005 & 0.01 & 0.1 & 0.03 & 0.05 & -0.04 & -0.15 & -0.1 \\
\hline & $p^{b}$ & 0.5 & 0.9 & 0.8 & 0.2 & 0.7 & 0.6 & 0.6 & 0.1 & 0.2 \\
\hline \multirow{2}{*}{7} & $r^{a}$ & -0.08 & 0.03 & -0.03 & 0.04 & -0.08 & $0.25^{*}$ & $0.3^{* * *}$ & $-0.33^{* *}$ & -0.01 \\
\hline & $p^{b}$ & 0.4 & 0.7 & 0.7 & 0.6 & 0.4 & 0.02 & 0.009 & 0.004 & 0.9 \\
\hline \multirow{2}{*}{8} & $r^{a}$ & -0.1 & 0.05 & -0.07 & 0.2 & 0.09 & 0.04 & 0.06 & $-0.38^{* * *}$ & -0.04 \\
\hline & $p^{b}$ & 0.3 & 0.6 & 0.5 & 0.06 & 0.44 & 0.7 & 0.5 & 0.001 & 0.6 \\
\hline \multirow{2}{*}{9} & $r^{a}$ & 0.07 & 0.1 & -0.1 & 0.04 & -0.12 & 0.06 & -0.1 & 0.15 & 0.1 \\
\hline & $p^{b}$ & 0.4 & 0.2 & 0.3 & 0.7 & 0.2 & 0.5 & 0.2 & 0.201 & 0.3 \\
\hline
\end{tabular}

*Significant ** Highly Significant 


\section{Mosul Journal of Nursing, Vol. 7, No. 2, 2019 ( 109-119 )}

Correlations of Total ENSS with Total JSS.

\begin{tabular}{|c|c|c|c|}
\hline \multicolumn{2}{|c|}{ Pearson Correlation } & Total ENSS & Total JSS \\
\hline \multirow{3}{*}{ Total ENSS } & $r$ & 1 & $\mathbf{- 0 . 0 6 4}$ \\
\cline { 2 - 4 } & $p$ & & 0.585 \\
\hline \multirow{3}{*}{ Total JSS } & $r$ & -0.064 & 1 \\
\cline { 2 - 4 } & $p$ & 0.585 & \\
\hline
\end{tabular}

\section{DISCUSSION}

Table 4-1 described the socio-demographic characteristics. As evidenced by the table, the highest percentage of studied sample were $(29.3 \%)$ in the age group of (30 to 34 years). While the lowest percentage $(1.3 \%)$ were between (20 to 24 years ) and (55 to 59 years).

In regard to the gender factor, approximately male and female had the same participation level (52\%) were male, while other remaining $(48 \%)$ of them were female. With relation to marital status, the majority $(82.7 \%)$ were married.

Regarding to graduation level, about three out of four $(74.7 \%)$ of the staff nurses had diploma degree in nursing. While the lowest percentage $(2.7 \%)$ had the Bachelors Degree of nursing science.

Regarding years of employment in mental health, the table showed that the highest percentage (37.3\%) had (6 to 10 years) of employment. While $(6.7 \%)$ of nurses had (21 to 25 years) of employment.

With regards to economic status, the table showed that majority (72\%) of them were barely sufficient, while $(10.7 \%)$ of them were Sufficient .

Concerning training course undertaken, the high percentage of sample (64\%) had participation in training course.

Finally, the table demonstrated that the majority of nurses $(76 \%)$ had profession fitting with interest.

Table 4-2 revealed that the overall mean of 'Expanded Nursing Stress Scale' (ENSS) was (2.47) indicated that total average of job stress that occurred in the workplace perceived by staff nurses in mental health hospitals was "Occasionally stressful to frequently stressful".
The subscale 'death and dying' had highest level percentage as indicated at the Mean (2.73), while the subscale 'Problems with peers' had the lowest level percentage from the total as indicated at the mean (2.02).

This finding of the study is similar to other studies conducted by Saleh et al. (2013) in Kingdom of Saudi Arabia which ENSS Mean $=(2.51)$, AbuRuz, (2014) .

In current study; subscale 'death and dying' takes the first order in the rank, has obtained the highest mean (2.73), which is related to all these meaning of items "Performing procedures that patients experience as painful", "Feeling helpless in the case of a patient who fails to improve", "Listening or talking to a patient about his or her approaching death", "The death of a patient", "The death of a patient with whom you developed a close relationship", "Physician(s) not being present when a patient die", and "Watching a patient suffer". Item "Physician(s) not being present when a patient die" take the highest order in domain Death and dying have (40\%) which is highly stressful events that frequently occurred in the workplace perceived by staff nurses at the mean $=3.19$.

The results of current study may be due to deep and direct contacts of nurses with patients for a long time (Kieft et al., 2014). Death by its nature is stressful and a source of suffering. It can affect them both in their work environment and outside of work. This is associated with poorer mental and physical health problem(Wilson and Kirshbaum, 2011).

Therefore, nurses show more symptoms of stress when they are in close relation dealing with death and dying and physicians not being present. 


\section{Mosul Journal of Nursing, Vol. 7, No. 2, 2019 ( 109-119 )}

While the subscales 'problems with peers' from ENSS in the current study has the lowest level percentage from the total as indicated in the mean ( 2.02 ) was least stressful subscale. It is related to all these items "Lack of opportunity to talk openly with other personal about problems in the work setting", "Lack of opportunity to share experiences and feelings", "Difficulty in working with a particular nurse (or nurses) in my immediate work setting", "Difficulty in working with a particular nurse (or nurses) in my outside work setting", "Lack of an opportunity to express to other personnel on the unit my negative feeling towards patients", have occasional stressful event perceived by staff nurses" and" Difficulty in working with nurses of the opposite sex". Within these last item "Difficulty in working with nurses of the opposite sex" takes the lowest order in domain problems with peers.

The current study findings may be as a result of adoption tolerance, openness culture and effective communications among nurses in work place. Besides there is satisfaction from organization's management, and respect of work rules, despite nurses reported suffering some stress in different mean score (Gifford, et al., 2002).

The findings in the table (4-3) revealed that the overall mean of job satisfaction was (4.08) indicating that there were the job satisfaction among nursing staff at mental health hospitals.

Subscale 'pay' had lowest level of satisfaction as indicated by the mean (3.11). While the highest level of job satisfaction in subscale 'Coworkers' as indicated by the Mean (4.7).

The job satisfaction scale items mean (4.08) indicates that total average are "satisfaction" because the mean score is greater than 4.00 slightly.

The majority of the nurses have expressed the lowest level of satisfaction regarding subscales 'pay' (salary) mean $=3.11$. This rated the lowest level of all subscales JSS.

Items "I feel I am being paid a fair amount for the work I do", "Raises are too few and far between", "I feel unappreciated by the organization when I think about what they pay me" and "I feel satisfied with my chances for salary increases". Included item "Raises are too few and far between" take the lowest level of satisfaction from the subscale pay at the means .
Payment has a major impact on job satisfaction. Low paid employees showed a low level of job satisfaction. Financial aspects especially salary was the most important aspect among all domains, because each employee needed livelihood to support his/ her family (Usman, 2013).

Nursing staff intend to more salary and without lack and delay. Most of them feel unsatisfied with their chances for salary increases.

While the subscale 'coworkers' from the current study take the highest level from the total of satisfaction mean $=(4.74)$, concerning all these items "I like the people I work with", "I find I have to work harder at my job because of the incompetence of people I work with", "I enjoy my coworkers", and" There is too much bickering and fighting at work". Last item "There is too much bickering and fighting at work" takes the highest order in subscale coworkers mean $=5.13$. It is regarded as one of the strengths of nurses staff in Sulaimani mental hospitals.

The researcher thinks about coworkers subscale noted that there were good relationships and cooperation among nursing staff without bickering or fighting at work (Rosales et al., 2013).

Table (4-4) indicate that there were several kinds of associations among the items of both scales. Nevertheless, only item 7 of ENSS showed significant positive correlations with items 6 and 7 of JSS. On the other hand, ENSS 1, 2, 7, and 8 were negatively correlated with JSS 8 .

In other words, increased nurses' stress in the subscale of 'uncertainty concerning treatment' was associated with significantly more job satisfaction in regards of 'operating conditions' and 'coworkers'. Whereas more nurse's stress in regards of 'death and dying', 'conflict with physicians', 'uncertainty concerning treatment', and 'patients and their families' was associated with significantly less job satisfaction in regard of the 'nature of work'.

Table (4-5) showed that there was no statistical significant correlation between total ENSS and total JSS.

In conclusion total ENSS and total JSS were not significantly correlated to each other.

In a comparative study about the impact of stress on job satisfaction between jordanian and saudi nurses, AbuRuz (2014) founded that there was a significant negative relationship between stress 


\section{Mosul Journal of Nursing, Vol. 7, No. 2, 2019 ( 109-119 )}

and job satisfaction for Jordanian nurses $\mathrm{r}(148)=-$ $0.630, p<.05$ and for Saudi nurses r $(98)=-0.437$, $\mathrm{p}<.05$. Another study conducted by Saleh et al. (2013) and Kamal et al. (2012) in Kingdom of Saudi Arabia in agreement goes with resulting this study "negative significant relationship between stress and job satisfaction among staff nurses" as indicated by (Pearson correlation $=-.437, \mathrm{P}<$ $0.05)$ for both.

Another study conducted by Mansour et al. (2014) at King Saud revealed that a significant positive relation between level of perceived stress and level of job satisfaction was found in this study $\mathrm{p}=0,009$.

These similarities and differences between the study results may be contributed to some reasons as: deference in place of study, size of the sample, environment influences, psychological condition of respondent, and etc.

Relating to this study, most of the nursing staff were satisfied with their jobs.

However, they were slightly stressed from their job environment especially in death and dying that led to a negative impact on the level of job stress (Edoho, et al.,2015). Also, regarding the domain salary which led to negative impacts on nurses job satisfaction, satisfied nurses did not correlate to nurses job stress in mental hospital. This referred to the fact that there was others factors slightly effected the satisfied nurses (Lorber and Skela, 2012).

\section{CONCLUSION}

According to the present study findings, the researcher can conclude that :-

1. Approximately (1/4) of participated nurses have not profession fits with interest.

2. Nurses had satisfied with their work. No bickering and fighting at work.

3. The lack and delay in payment (salary) are a major cause of increasing job stress and decreasing job satisfaction, although the level of job stress among nurses is not recorded high and most of them satisfied with their job.

4. There were a good relationship and effective communication among nurses staff.

\section{RECOMMENDATIONS}

The study recommends :

1. Employing Bachelor and Master degree in Nursing Sciences with achieving their desire in working at mental health hospitals.

2. Improving the payment and incentives for nurses working in mental hospitals to keep nurses from turnover or change the setting of work, and to encourage the newly graduate nurses to join in these places.

3. Implementing excessive training courses inside and outside country for nurses working in psychiatric hospitals. This is to increase or at least maintain their skills which increases satisfaction and decreases job stress.

4. Deepening coordination between the Ministry of Health and Higher Education to achieve hospitals requirements about Master and Bachelor degrees in nursing, and number of nurses in psychiatric nursing.

5. Adding stress management programmes in syllabus of nursing education to make them manage their own stress in the future.

6. Adopting effective relaxation programs and strategies to reduce amount of job stress. Thus, this will increase job satisfaction which will be reflected on patient care quality.

7. Documenting the source and the extent of stress in any health care unit or organization is essential for successful interventions.

\section{REFERENCE}

AbuRuz, M. (2014), 'A Comparative Study about the Impact of Stress on Job Satisfaction Between Jordanian and Saudi Nurses', European Scientific Journal, 10(17), Pp. 162-172.

Al Rasasi, A., Al Faisal, W., El Sawaf, E. and Hussain, H., (2015), 'Work- Related Stress among Nurses Working in Dubai, A Burden for Healthcare Institutions', American Journal of Psychology and Cognitive Science, 1(2), Pp. 6165.

Al-Makhaita, H., Sabra, A. and Hafez, A., (2014) 'Predictors of Work-Related Stress among Nurses Working in Primary and Secondary Health Care Levels in Dammam, Eastern Saudi Arabia', 


\section{Mosul Journal of Nursing, Vol. 7, No. 2, 2019 ( 109-119 )}

Journal of Family and Community Medicine, 21(2), Pp. 79-90.

Cang-Wong, C., (2009), 'Nursing Responses to Transcultural Encounters: What Nurses Draw on When Faced With a Patient from another Culture', The Permanente Journal, 13(3), Pp.31-38.

Edoho, S.A.P., Bamidele, E., Neji, O.I. and Frank, A.E., (2015). Job Satisfaction among Nurses in Public Hospitals in Calabar, Cross River State Nigeria. American Journal of Nursing Science, 4(4), pp.231-237.

Finney, C., Stergiopoulos, E., Hensel, J., Bonato, S. and Dewa, C. (2013) 'Organizational Stressors Associated with Job Stress and Burnout in Correctional Officers: A Systematic Review', Bmc Public Health, 13(1), Pp. 82.

Gifford, B.D., Zammuto, R.F., Goodman, E.A. and Hill, K.S., (2002). The relationship between hospital unit culture and nurses' quality of work life/Practitioner application. Journal of Healthcare management, 47(1),Pp.(13-23).

Kamal, S., Al-Dhshan, M., Abu-Salameh, K. and Abuadas, F. (2012) 'The Effect of Nurses' Perceived Job Related Stressors on Job Satisfaction in Taif Governmental Hospitals in Kingdom of Saudi Arabia.', Journal of American Science, 8(3), Pp. 119-125.

Kawano, Y., (2008) 'Association of Job-Related Stress Factors with Psychological and Somatic Maldonado, M., (2014), 'How stress affects mental health| world of psychology'. Available at: http://psychcentral.com/blog/archives/2014/02/25/ how-stressaffects- mental-health / (Accessed: 5 August 2016).

Mansour, E., Taha, N., El-Araby, M. and Younes, H., (2014), 'Nurses' Perceived Job Related Stress and Job Satisfaction in Two Main Hospitals in Riyadh City', 11(8), Pp. 336-341.

Mark, G. and Smith, A., (2011), 'Occupational Stress, Job Characteristics, Coping, And the Mental Health of Nurses', British Journal of Health Psychology, 17(3), Pp. 505-521.

Melo, M., Barbosa, M. and Souza, P. (2011) 'Job Satisfaction of Nursing Staff: Integrative Review', Revista Latino-Americana De Enfermagem, 19(4), Pp. 1047-1055.

Rosales, R., Labrague, L. and Rosales, G. (2013) 'Nurses' Job Satisfaction and Burnout: Is There a
Symptoms among Japanese Hospital Nurses: Effect of Departmental Environment in acute Care Hospitals', Journal of Occupational Health, 50(1), Pp. 79-85.

Kieft, R., De Brouwer, B., Francke, A. and Delnoij, D., (2014), 'How Nurses and Their Work Environment Affect Patient Experiences of the Quality of Care: A Qualitative Study', BMC Health Services Research, 14(1), Pp. 249-257. Doi: 10.1186/1472-6963-14-249.

Kumar, R., Kaur, G. And Dhillon, A. (2015) 'Organizational Role Stress and Job Satisfaction among Nurses', Journal of Mental Health and Human Behaviour, 20(2), P. 71.

Li, L., Hu, H., Zhou, H., He, C., Fan, L., and Sun, T. (2014) 'Work Stress, Work Motivation and Their Effects on Job Satisfaction in Community Health Workers: A Cross-Sectional Survey in China', BMJ Open, 4(6), Pp. E004897-E004897.

Long, C., Kowang, T., Ping, T. and Muthuveloo, R., (2014), 'Investigation on The Impact of Job Stressors on Nurses in Malaysia', Asian Social Science, 10(4), Pp.67-75.

Lorber, M. and Skela Savič, B., (2012), 'Job Satisfaction of Nurses and Identifying Factors of Job Satisfaction in Slovenian Hospitals', Croatian Medical Journal, 53(3), Pp. 263-2.

Connection?', International Journal of Advanced Nursing Studies, 2(1), Pp. 1-10.

Sabee, A., (2013), 'Stress is Now a Major Problem in Many Countries around the World', Available at: Http://Www.Testbig.Com/Ielts-Essays/StressNow-Major- Problem-Many-Countries-AroundWorld-What-Are-Some-Factors-Modern (Accessed: 5 August 2016).

Saleh, A., Saleh, M. and AbuRuz, M., (2013), 'The impact of stress on job satisfaction for nurses in King Fahad Specialist Hospital-Dammam- KSA', Journal of American Science, 9(3), pp. 371-377.

Shikieri, A. and Musa, H., (2012), 'Factors Associated with Occupational Stress and Their Effects on Organizational Performance in A Sudanese University', Creative Education, 03(01), Pp. 134-144.

Sullivan, D. (2013) 'Rising To The Challenge of Health Care Reform with Entrepreneurial and 
Mosul Journal of Nursing, Vol. 7, No. 2, 2019 ( 109-119 )

Intrapreneurial Nursing Initiatives', Creative Nursing, 19(3), Pp. 166-167.

Usman, S. (2013) 'Effect of Salary and Stress on Job Satisfaction of Teachers in District Sialkot, Pakistan', IOSR Journal of Humanities and Social Science, 15(2), Pp. 68-74.

Watson, W., (2013), U.S. Employers Rank Workplace Stress as Top Workforce Risk Issue. Available At: Https://Www.Towerswatson.Com/En/Press/2013/1 1/ Us-Employers-Rank-Stress-As-Top-WorkforceRisk-Issue (Accessed: 3 October 2016).

Wen-Hsien, H., Ching, C., Ying-Ling, S., and Rong-Da, L. (2009) 'Effects of Job Rotation and Role Stress among Nurses on Job Satisfaction and Organizational Commitment', BMC Health Services Research, 9(1), Pp. 8-17.

Wilson, J. and Kirshbaum, M. (2011) 'Effects of Patient Death on Nursing Staff: A Literature Review', British Journal of Nursing, 20(9), Pp. 559-563. 